DOI: 10.22559/folklor.999

folklor/edebiyat, cilt:25, sayı:99, 2019/3

\title{
Rica Ediminin Türkçeyi Yabancı Dil Olarak Öğrenenler Tarafından Kullanımları ${ }^{1}$
}

\author{
Uses of Request Act by Learners of Turkish as a Foreign \\ Language
}

\author{
Hatice Altun Alkan* \\ Derya Yaylı*
}

\section{$\ddot{O} \mathbf{z}$}

$\mathrm{Bu}$ çalışmanın amacı, Austin ve Searle tarafindan oluşturulan Söz Edimleri Kuramı doğrultusunda, rica söz edimlerinin farklı bağlamlar karşısında Türkçeyi yabancı dil olarak öğrenenler tarafından kullanımlarını tespit etmektir. Bu çalışmada betimsel modelde nitel bir araştırma deseni kullanılmıştır. Araştırmada 75 birinci dil Türkçe konuşuru ve 262 ikinci dil Türkçe konuşurunun oluşturduğu iki örneklem grubundan veriler uygun örnekleme yoluyla toplanmıştır. Araştırmanın verileri Söylem Tamamlama Testi aracılığı ile toplanmıştır. Araştırmanın probleminin çözümlenmesinde Blum-Kulka ve Olshtain'in sınıflandırmasında yer alan Blum-Kulka'nın oluşturduğu rica stratejilerinden faydalanılmıştır. Bu araştırmanın sonuçlarına genel olarak bakıldığında birinci dil Türkçe konuşurlarının rica etme ediminin izin/onay isteme ve bilgi alma alt ulamlarında ikinci dil olarak Türkçe

1 Bu çalışma, birinci yazarın "Rica ediminin Türkçeyi yabancı dil olarak öğrenenler tarafından kullanımları” başlıkl1, Pamukkale Üniversitesi Eğitim Bilimleri Enstitüsü tarafından kabul edilmiş olan yüksek lisans tezinden üretilmiş ve Pamukkale Üniversitesi Bilimsel Araştırma Projeleri Koordinasyon Birimi tarafından desteklenmiştir.

* Yüksek lisans öğrencisi, Pamukkale Üniversitesi, Eğitim Bilimleri Enstitüsü, Türkçe ve Sosyal Bilimler Eğitimi Anabilim Dalı, haltun7878@gmail.com

** Prof. Dr., Pamukkale Üniversitesi, Eğitim Fakültesi, Türkçe ve Sosyal Bilimler Eğitimi Bölümü, dyayli@pau. edu.tr 
öğrenenlerden farklı stratejileri kullandıkları, ancak eylem isteme alt ulamında genellikle aynı stratejileri tercih ettikleri görülmüştür. Bunun yanında kişiler arası ilişkinin, yaşın ve toplumsal statünün, dilsel yetinin birinci dil olarak Türkçe konuşurlarda verilen yanıtları belirleyici olduğu da elde edilen sonuçlar arasındadır.

Anahtar sözcükler: Edimbilim, Türkçe ögrretimi, söz edimler, rica söz edimi

\begin{abstract}
The aim of this study is to determine the uses of request speech acts in different contexts by those learning Turkish as a foreign language, in the light of the Speech Act Theory developed by Austin and Searle. This study has a qualitative research design in a descriptive model. In the study, data from two sample groups consisting of 75 first language Turkish speakers and 262 second language Turkish speakers were collected by appropriate sampling. The data of the study were collected by the Discourse Completion Test. In the analysis of the sub-problems of the study, Blum-Kulka's request strategies, which are included in Blum-Kulka and Olshtain's classification, were used. When the results of the study were examined, it was seen that the second language Turkish speakers used request speech act in situations they face for the first time or rarely, and that the first language Turkish speakers chose to use request speech acts rather based on their intuition, grammar knowledge or language transfer. Evaluating the results obtained in this research in general, the first language Turkish speakers who learned Turkish as the mother tongue used different strategies than those learning Turkish as a second language in the permission/approval and information request subcategories of request speech acts but tended towards the same strategies in general in action request subcategories. In addition, it was seen that the interpersonal relationship, age, social status, and linguistic ability affected the responses frequently in the first language Turkish speakers whereas they did not adequately affect the responses in the foreign students given that the relationship or status was not fully known.
\end{abstract}

Keywords: Pragmatics, Turkish language teaching, speech acts, request speech act

\title{
Giriş
}

Bireyin içinde yer aldığı toplumun ya da yerleşik düzenin değerleri ve zihniyetiyle uyuşmÇağdaş dilbilim kuramları ve yöntemleriyle ilişki içinde olan ikinci dil öğretimi, diğer alanlardan birçok araştırmacının da ilgi odağı durumuna gelmiştir. Farklı alanlarda yürütülen çalışmalar daha çok ikinci dilin edinim ve kullanım süreç ve biçimlerini kapsamaktadır (Ellis, 1994: 37; Gass ve Houck, 1999: 25; Trosborg, 1995: 58). Çağdaş dilbilimin önde gelen kuramcılarından Chomsky, birinci dil konuşurunun kullandığı cümle yapıları için kişinin dile ilişkin sezgisel bilgisine edinç, edinç doğrultusunda konuşma ya da yazma sırasında oluşan cümle üretimine ise edim adını vermiştir (Kıran ve Kıran, 2013: 82). Chomsky üretimsel dönüşümlü dilbilgisi kuramında ise, yeti kavramıyla bir dilin yapısının kişinin zihninde nasıl çalıştığını öğrenmeyi, edim kavramıyla da dilin gündelik yaşamda nasıl yer aldığını, yazılı ve 
sözlü iletişim sırasında nasıl kullanıldığını açıklamaktadır (Aktaş, 2005: 45-57). Günümüzde dilin yapısını açıklamak için bu kavramların yanında iletişim yetisi, yani bir dile ait toplum ile nitelikli bir iletişim ortaya koymak için gereksinim duyulan bilgi ve becerileri edinmiş olma (Genç’ten (2000) aktaran Aktaş, 2005: 45-57) da önem kazanmıştır. Bu yeti, belirli durumlarda kim kiminle nasıl konuşabilir ya da neyi ne zaman, nerede, konuşabilir; ne zaman sessiz kalınır; aynı ve farklı statüdeki kişilerle nasıl konuşulur; farklı bağlamlar doğrultusunda bilgi nasıl istenir ya da verilir; rica ve istek nasıl gerçekleştirilir; nasıl emir verilir gibi söz edimlere ilişkin uygun kullanımları içerir (Demircan, 1990: 35-66).

İkinci dil öğretim yöntemlerinin gelişimini 1960’lı yıllardan itibaren etkileyen ve iletişimci yaklaşım, işlevsel-kavramsal yaklaşım, eylemsel yaklaşım gibi yaklaşımların yapı taşlarından olan edimbilim ve söz edimleri, birinci dil olarak Türkçe konuşurları (bundan böyle BDTK) kadar ikinci dil olarak Türkçe konuşurlarına (bundan böyle İDTK) da farklı yönden bakmayı sağlamıştır (Polat, 2010: 43).

\section{Söz edimleri kuramı}

Austin (1970)'in kavram önderliğini yaptığı ve daha sonra öğrencisi Searle (2000) ile geliştirilen edimbilim ve söz edimi kuramında kullanılan sözceler, taşıdıkları etkisözel ve edimsözel anlama, kullanılan bağlama, konuşucu ve dinleyicinin amacına, birbirlerine göre konumuna ve varsayımlarına göre açıklanmaktadır (Kocaman, 2009: 379-380), ayrıca söz edimi kuramı söz eylem kuramı ve dil edimi kuramı biçiminde de kullanılmaktadır. Söz edimi, gerçekleştirilmesi için dilin gerektiği eylemleri ortaya çıkarmayı sağlayan ve bireylerin karşılıklı durumlarını değiştirmeyi amaçlayan en küçük anlam birimidir (Çelebi, 2014: 79; Özdemir, 2016: 18). Austin'e göre, bir söz edimi üretirken bir kişi aynı anda üç farklı edim gerçekleştirebilir.

“Edim (A) - Düzsöz edimi (Dillendirme edimi):

Bana, "üzerine ateş et” biçiminde söylemek isteyerek ve $o$ kişisine gönderme yaparak “Ona ateş et!” dedi.

Edim (B) - Edimsöz edimi:

Ona ateş etmemem için bana öğüt verdi (baskı yaptı ya da bana emir verdi, vb).

Edim (C) - Etkisöz edimi:

Ona ateş etmem için beni ikna etti” (Austin, 1970: 114; Özdemir, 2016: 21).

Söz edimleri kuramını geliştiren Searle, söz edimlerini “insanın dille olan iletişiminin eksiksiz en küçük birimi” biçiminde tanımlar ve "insan davranışı araştırmalarının bir bölümünü de dil araştırmalarının oluşturduğunu" (2009: 228) söyler. Searle’ün söz edimleri ile ilgili farklı düşündüğü noktalardan biri de, edimsöz ediminin içeriği ve gücü arasındaki farktır. Bir söz edimi önerme içeriği ve edimsöz gücü biçiminde iki kısımdan oluşmaktadır (Searle, 2006: 158):

"Evi temizle!" (emir)

"Bugün evi sen temizlesen nasıl olur?” (öneri) 
"Keşke evi temizlesen.” (istek)

sözcelerinde birbirinden farklı üç edimsöz gücü bulunmaktayken “evi temizlemek” biçiminde tek bir önerme içeriği yer almaktadır.

\subsection{Rica etme söz edimi}

Konuşma sırasında o eylemin gerçekleştirildiği ifadeler söz edimler biçiminde belirtilmektedir (Searle, 2000: 46). Austin bir söz söylendiği esnada iletişimsel olarak bir edim de gerçekleştirildiğine önem vermiş ve bir dildeki edim sayısı kadar söz edim olduğunu söylemiştir (Erdem, 2014: 115-142). Söz edimlerinin, söz eylemlerin herkes tarafından kabul edilen standart bir sözce uzunluğu bulunmamaktadır ve bu nedenle birden çok sözceden oluşabileceği gibi, bağlam anlaş1lıyorsa eksiltili bir sözce de söz edim olabilir (Aslan, 2005: 114-117). Bu durumda ricalar; konuşucu tarafından istenen bazı sözel ya da sözel olmayan edimleri dinleyiciye iletme kaygısı taşıyan emir, soru, bildirim, istek sözceleri ya da eksiltili yapılar biçiminde oluşturulan iletişimsel amaçlar biçiminde açıklanabilir (Eken, 2008: 12).

Konuşmacının yararı için karşısındaki kişiden bir eylem gerçekleştirmesini istemesi de rica olarak adlandırılmaktadır (Trosborg, 1995: 48). Ricalar da bağlam ile anlam kazanan edimlerdir. Austin rica eylemine "kullanım-belirticiler" sınıfında yer verirken, Searle emir, istek ve ricaları yönlendirici söz edimleri içerisine almaktadır (Austin, 2009: 166-169).

$\mathrm{Bu}$ çalışmanın temelinde de yer alan rica alt ulamlarını değerlendiren Dore (1978) rica amacını, rica etme beklentisi ile üretilen sözceler biçiminde açıklamaktadır. Dore konuşucunun, gerçekleştirilmesini istediği eylemleri dinleyiciye iletme endişesiyle ürettiğini söylemekte ve bu amaç doğrultusundaki sözceleri bilgi alma amaciyla üretilen ricalar ("N'oldu?"), eylem isteme amaciyla üretilen ricalar ("Gidelim.") ve izin/onay isteme amaciyla üretilen ricalar ("Yiyebilir miyim?”) (Dore, 1978: 87-111) biçiminde üç alt ulamda değerlendirmektedir.

\subsection{Blum-Kulka ve Olshtain'a göre rica stratejileri}

Blum-Kulka ve Olshtain (1984) rica stratejilerini doğrudan, geleneksel dolaylı ve geleneksel olmayan dolaylılık olarak üç gerçekleştirim biçimi altında incelemiştir. $\mathrm{Bu}$ sınıflandırmanın amacı verilen bağlam karşısında uygun stratejinin seçimini sağlamaktır. Toplumsal ilişkilerde bağlamlar duruma, statüye, yaşa vb. özelliklere göre çeşitlilik gösterir. $\mathrm{Bu}$ nedenle aynı strateji farklı bağlamlarda değişebileceği için farklı rica stratejilerini tercih etmek gerekebilir. Blum-Kulka ve Olshtain (1984), istekleri ve ricaları CCSARP (Çapraz Kültürel Konuşma Gerçekleştirme Projesi) doğrultusunda gruplandırmışlardır. Alanyazında yapılan sınıflandırmaların en kullanışlı olanı olduğu için bu çalışmada Blum-Kulka ve Olshtain (1984) stratejileri temel alınmıştır. 
Tablo 1. Blum-Kulka ve Olshtain Stratejilerine Göre Rica Ulamlarl

\begin{tabular}{|c|c|}
\hline Rica Ulamları & Stratejiler \\
\hline $\begin{array}{l}\text { 1) Doğrudan anlatım: Emirler ve eylem içeren } \\
\text { fiiller gibi doğrudan istekte bulunmak. }\end{array}$ & $\begin{array}{l}\text { * Türetilebilir durum (mood derivable) } \\
* \text { Doğrudan eylem (explicit performative) } \\
* \text { Sinırlandırılmış eylem (Hedged perfor- } \\
\text { mative) } \\
\text { *Yer Belirleme - zorunluluk ifadesi (Lo- } \\
\text { cution } \\
\text { derivable obligation statement) } \\
\text { *İstek ifadesi (want statement) }\end{array}$ \\
\hline $\begin{array}{l}\text { 2) Geleneksel-alışılmış dolaylı düzey: Rica söz edi- } \\
\text { mi gerçekleştirilmeden önce kullanıma hazırlayıcı } \\
\text { dolaylı düzey ve geleneksel dil kullanımlarında } \\
\text { rica istek alt ulamı biçiminde kullanılır. Genel ola- } \\
\text { rak dolaylı söz edimleri biçiminde bilinirler (Onu } \\
\text { alabilir misin?). }\end{array}$ & $\begin{array}{l}\text { * Öneri ifadesi (suggestory formula) } \\
\text { * Hazırlayıc1 durumlara atıf (reference to } \\
\text { preparatory } \\
\text { condition) }\end{array}$ \\
\hline $\begin{array}{l}\text { 3) Geleneksel olmayan dolaylı düzey: Ricayı ya } \\
\text { bağlamsal ipuçları ile (Burası sıcak) ya da eylemin } \\
\text { yaşama uyarlanması için gereksinim duyulan öğe } \\
\text { ya da nesneyle olan ilişkisi ile gerçekleştirme biçi- } \\
\text { mindedir. Geleneksel olmayan dil kullanımlarında } \\
\text { ricanın gerçekleştirilmesi ipuçlarına, sezdirimlere } \\
\text { kişinin durumuna bağlıdır. (Pencerenin açılmasını } \\
\text { dolaylı olarak rica etmek: burası sıcak) }\end{array}$ & $\begin{array}{l}\text { * Güçlü ipuçları (Strong hints) } \\
\text { * Hafif ipuçları (Mild hints) }\end{array}$ \\
\hline
\end{tabular}

Tablo 1.'e göre doğrudan eylem ifadesi stratejisinde konuşucu doğrudan istekte bulunur ya da emir fiillerinden oluşan sözceler kullanır. Örneğin "Yüksek sesle konuşmamanızı rica ederim." kullanımı açıkça edimi belirten doğrudan eylem ifadesi stratejisidir. Türetilebilir durum stratejisinde eylemin kullanımındaki dilbilgisel durum ricanın gerçekleştirilme gücünü ortaya çıkarır ve doğrudan anlatım içerir. "Beni rahat bırak." biçimindeki bir kullanım türetilebilir durum stratejisine örnek olarak verilebilir (Tabar, 2012: 237-243). Sinırland1rılmış eylem stratejisinde konuşmacı tarafından ricanın gerçekleştirilme gücü açıkça ifade edileceği için bu strateji de doğrudan anlatım rica gerçekleştirim ulamı içerisinde bulunmaktadır. "Kursunuzu bir saat öne almanızı rica etmek istiyorum” ifadesi bu stratejinin kullanımına örnek olarak verilebilir. Yer belirleme ve zorunluluk ifadesi stratejisi de doğrudan eylem ifadesi stratejisi ve türetilebilir durum stratejisi ile aynı ulamda yer almaktadır. Örneğin “Arabanı çekmek zorundasın” diyen bir konuşucu, dinleyiciyi mecbur birakan bir zorunluluk sözcesi kullandığı için bu stratejiyi seçmiştir. Birinci ulamda bulunan ve son strateji olan istek ifadesi stratejisine verilen örnek "Kitabını bir süreliğine ödünç alabilir miyim?" biçimindedir (Tabar, 2012: 237-243). Geleneksel-alışılmış dolaylı düzey ulamında yer alan öneri ifadesi stratejisinde genellikle dolaylı bir rica kullanımı ile gerçekleştirilen öneri vardır. "Bugün denize gitmeye ne dersin?” ifadesi öneri ifadesini içeren rica gerçekleştirilmeden hemen önce kullanılan bir sözcedir. İkinci ulamda bulunan diğer bir strateji olan hazırlayıcı 
durumlara atıf stratejisinde söz, dilin alışılagelmiş biçimlerinde hazırlayıcı durumlara atıfta bulunur (örneğin, gerçekleşme olasılığı ya da eylem için isteklilik). Bu strateji rica gerçekleşmeden önce kullanıma hazırlayıcı sözceler olarak ifade edilmektedir (Tabar, 2012: 237-243). "Bana biraz borç verebilir misin merak ediyorum." ifadesinde rica gerçekleşmeden önce ricaya hazırlayıcı bir kullanım görülmüştür. Son ulamda yer alan güçlü ipuçları stratejisinde söz edimi ima eden durumlar için gerekli olan unsurlar ya da nesnelere göndermeler bulunur (Jalilifar, 2009: 46-61). Bu stratejide rica güçlü bir biçimde sezdirilir. "Bu kitap çok sıkıcı" ifadesinde amaç kitabı bırakmaktır ve rica güçlü bir biçimde sezdirilmektedir (Aktaş, 2005: 45-57). Son strateji olan ve geleneksel olmayan dolaylı düzey rica gerçekleştirim ulamında yer verilen hafif ipuçları stratejisinde söz ricaya göndermede bulunmaz, ancak dolaylı olarak eyleme imada bulunarak rica olarak düşünülebilinir (Jalilifar, 2009: 46-61). “Ви kопиуи bir saatten fazla süredir dinliyoruz." ifadesinde sıkılan birinin dinleme eylemini bırakmak için hafif biçimde sezdirimde bulunduğu görülmektedir.

Söz edimlerinin yerinde kullanımı toplumsal ilişkilerde önemli bir yere sahiptir. Türkiye'de belli bir süre yaşayan öğrenciler tarafından rica kullanımlarının dolaylılık/dolaysızlık/uygunluk/uygunsuzluk stratejileri açısından anlaşılamaması sonucunda; öğrenenlere incelik stratejilerinin edindirilmediği, hangi bağlamsal durumların geçerli olduğunun fark ettirilmediği ortaya çıkmaktadır (Erdem, 2014: 115-142). Özellikle ikinci dil olarak Türkçe öğretiminde söz edimlerinin ne olduğu, hangi durumlarda nasıl kullanıldığı ve bağlamın söz edimlerinin kullanımındaki öneminin belirlenmesi gereksinimi ortaya çıkmıştır. Bu çalışmada ikinci dil olarak Türkçe öğrenenlerin bilgi alma, eylem isteme, izin/onay isteme ulamlarında toplanan rica edimlerini ne düzeyde kullandıklarının görünümleri incelenirken ikinci dil olarak Türkçe öğrenenlerin dolaylı rica edimlerini kullanmasında bağlamın ve toplumsal statünün önemi belirlenmeye çalışılmıştır.

\section{Yöntem}

Bu çalışma betimsel modelde gerçekleştirilen nitel bir araştırma desenine sahiptir (Yıld1rım ve Şimşek, 2006: 34-35). Standartlardan yola çıkarak değerlendirmeler yapmak ve olaylar arasındaki ilişkileri analiz etmek için inceleme sırasında doğal şartları bozmadan ya da inceleme gerçekleştirilen ortamda değişiklik yapmadan araştırmanın yürütülmesi nedeniyle bu desen kullanılmıştır.

\subsection{Evren ve örneklem}

Araştırmanın evrenini Türkiye'de üniversiteler bünyesindeki dil öğretim ve araştırma merkezlerinde Türkçe öğrenen yabancı öğrenciler oluşturmaktadır. Araştırmada yer alan gruplar, betimsel araştırma yöntemlerinden uygun/kazara örnekleme yöntemiyle belirlenmiştir (Balc1, 2009: 190). Araştırma sürecinde iki örneklem grubundan veri toplanmıştır. İlk olarak BDTK örneklemi uygun örnekleme yöntemiyle ve gönüllülük esasıyla belirlenmiştir. IDTK öğrenci grubunu ise Pamukkale Üniversitesi PADAM'da Türkçe öğrenen B düzeyindeki öğrenciler, Sakarya Üniversitesi TÖMER'de Türkçe öğrenen B ve C düzeyindeki öğrenciler, Gaziantep Üniversitesi TÖMER'de Türkçe öğrenen C düzeyindeki öğrenciler, Dokuz 
Eylül Üniversitesi DEDAM'da Türkçe öğrenen B ve C düzeyindeki öğrenciler, Ankara Üniversitesi İzmir TÖMER'de Türkçe öğrenen C düzeyindeki öğrenciler oluşturmuştur. A düzeyindeki öğrencilerin verdiği yanıtlar çalışmanın amacı açısından yeterli düzeyde olmadığı için bu gruptan toplanan veriler araştırma dışı tutulmuştur.

\subsection{Verilerin toplanması}

$\mathrm{Bu}$ çalışmanın verileri Söylem Tamamlama Testi ile toplanmıştır. Söylem Tamamlama Testi, verilen bir bağlam karşısında BDTK'ların ve İDTK'ların ne söyleyebileceklerini yani üretecekleri sözceleri belirmeyei amaçlayan bir veri toplama aracıdır. Veri toplama sürecinde öncelikle Söylem Tamamlama Testi maddelerini oluşturmak için Pamukkale Üniversitesi PADAM'da öğrenim gören on beş öğrenciden son iki hafta içerisinde yaşadıkları ve karşılarındaki kişilerden istekte bulundukları herhangi bir durum için verilen rica anı formuna oluşturdukları diyalogları yazmaları istenmiştir. Elde edilen veriler ile söylem tamamlama testinin bağlamları hazırlanarak test oluşturulmuştur. Daha sonra ikinci ya da üçüncü dil olarak Türkçe öğrenen yabancı öğrenciler için oluşturulan test farklı tarihlerde öğrenenlere uygulanmıştır. Araştırma 328 İDTK'ya uygulanmıştır. Öğrencilere doldurtulan testin kişisel bilgi bölümü değiştirilerek aynı test 85 BDTK’ya aynı ay içerisinde doldurtulmuştur.

\subsection{Verilerin analizi}

Verilerin değerlendirilmesi sonucunda A düzeyindeki öğrencilerin bağlamları anlamadıkları, yeterli ve uygun yanıtlar veremedikleri görülerek bu öğrenciler araştırma dışı tutulmuştur. Üç yüz yirmi sekiz İDTK'ya uygulanan testlerin 262'si geçerli sayılırken, 85 BDTK'ya uygulanan testlerin 75'i geçerli sayılmıştır. Elde edilen verilerden BDTK'ların bağlamlar karşısında verdikleri yanıtlar standart kullanımlar biçiminde belirlenerek değerlendirmede temel alınmıştır. Çalışmanın verileri "insanların söyledikleri ve yazdıklarının açık talimatlara göre kodlanarak nicelleştirilmesi-sayısallaştırılması süreci olarak tanımlanan” (Balc1, 2009: 189) içerik çözümlemesi tekniği yardımıyla uygun rica alt ulamında kullanılan Blum-Kulka ve Olshtain'in (1984) oluşturduğu dokuz rica stratejisine göre incelenmiştir.

Değerlendirmenin güvenirliğini ve geçerliğini arttırmak için araştırma dişından üç uzmana değerlendirme yaptırılmıştır. Değerlendiriciler arasındaki uyuma bakıldığında; verilen bağlamlara göre standart tek bir doğrunun olmadığı göreceli doğruluk derecesi farklılaşabildiği için uygun ve uygun olmayan biçiminde kullanımlar olduğu görülmüştür. Bu yöndeki çok küçük olan belirsizlikler tartışma ve uzlaşma yoluyla giderilmiştir.

\section{Bulgular}

Bu çalışmada İDTK'ların rica söz edimlerini kullanım becerileri, çalışma için oluşturulan 10 bağlam içi duruma verdikleri yanıtlar doğrultusunda incelenmiştir. Ayrıca yabancı dil olarak Türkçe öğrenenlerin bilgi alma, eylem isteme, izin/onay isteme ulamlarında elde edilen rica edimlerini ne düzeyde kullandıklarının belirlenmesi, yabanıı dil olarak Türkçe öğrenenlerinin rica edimlerini kullanmasında bağlamın ve toplumsal statünün yerinin irdelenmesi amaçlanmaktadır. Söylem Tamamlama Testi sorularına verilecek yanıtlar, İDTK'ların bağ- 
lamlar karşısında tercih ettikleri rica strateji kullanımlarının sayısal ortalamalarıyla belirlenmiştir. Ardından, BDTK'ların aynı bağlamlara verdikleri yanıtlar standart kullanımlar olarak belirlenerek IDTK'ların verdikleri yanıtlar ile karşılaştırılmıştır.

\subsection{Eylem isteme ulamında rica etme stratejilerinin dağılımı}

Çalışmaya katılan İDTK'lara ve BDTK'lara rica söz edimlerinin eylem isteme alt ulamında üç bağlam içi durum verilmiştir. Konuşurlardan bu bağlamlar karşısında, çok düşünmeden uygun buldukları sözceyi yazmaları istenmiştir. Verilen bağlam içi durumlara göre kullanılan stratejiler şöyledir:

\section{Bă̆lam:}

Pazartesi günü matematik sınavınız var. Bu derste çok başarılı olan bir arkadaşınızın pazar günü size ders çalıştırmasını istiyorsunuz. Arkadaşınızdan size pazar günü yardım etmesini nasll istersiniz?

Tablo 2. Dördüncü Bağlama Yönelik Başvurulan Rica Etme Stratejilerinin Dağılımı

\begin{tabular}{lllll}
\hline Stratejiler & BDTK & & İDTK & \\
& $f$ & $\%$ & $f$ & 32 \\
\hline 1. Türetilebilir durum & - & - & 84 & 51 \\
2. Doğrudan eylem & 23 & 31 & 132 & 11 \\
3. Sınırlandırılmış eylem & 19 & 25 & 28 & - \\
4. Yer belirleme-Zorunluluk & - & - & - & 2 \\
5. İstek ifadesi & 12 & 16 & 6 & - \\
6. Öneri ifadesi & - & - & - & 3 \\
7. Hazırlayıcı durumlara atıf & 12 & 16 & 8 & 1 \\
8. Güçlü ipuçları & 9 & 12 & 4 & - \\
9. Hafif ipuçları & - & - & - & 100 \\
Toplam & 75 & 100 & 262 &
\end{tabular}

Tablo 2.'de grupların dördüncü bağlam ile ilgili rica strateji türleri ve kullanımlarının dağılımları belirtilmektedir. Bu yanıtlar incelendiğinde BDTK'lar \%31 oranla en çok doğrudan eylem ifadesi stratejisini kullanırken IDTK'ların da \%51 oranla doğrudan eylem ifadesi stratejisini kullandıkları görülmüştür. Bunun yanında bu bağlamda öneri, yer belirleme-zorunluluk ve hafif ipuçları stratejilerine iki grubunda değinmediği görülmüştür. Dördüncü bağlama ilişkin BDTK'lardan birinin doğrudan eylem ifadesi stratejisindeki yanıtı "Kardeşim sen matematikte benden daha başarılısın, pazar günü müsaitsen pazartesi günkü sınav için rica etsem birlikte çalışabilir miyiz?” (Katılımc1, 18) biçimindeyken aynı bağlamda ve aynı stratejide yabancı dil öğrenenlerden birinin yanıtı "Pazar günü matematik çalıştır.” (Katılımcı, 214) biçimindedir. 


\section{Bă̆lam:}

Şehir dışından bir arkadaşınız sizi ziyarete geldi ve ona şehri gezdiriyorsunuz. Şehri gezerken fotoğraf çektirmek istiyorsunuz. O sırada bir adam görüyorsunuz. Ondan sizin fotoğrafınızı çekmesini nasıl istersiniz?

Tablo 3. Beşinci Bağlama Yönelik Başvurulan Rica Etme Stratejilerinin Dağılımı

\begin{tabular}{lllll}
\hline Stratejiler & BDTK & & İTK & \\
& $f$ & $\%$ & $f$ & $\%$ \\
\hline 1. Türetilebilir durum & 10 & 13 & 32 & 12 \\
2. Doğrudan eylem & 28 & 37 & 125 & 48 \\
3. Sinırlandırılmış eylem & 12 & 16 & 28 & 11 \\
4. Yer belirleme-Zorunluluk & 5 & 7 & 6 & 2 \\
5. İstek ifadesi & 12 & 16 & 68 & 26 \\
6. Öneri ifadesi & - & - & - & - \\
7. Hazırlayıcı durumlara atıf & 5 & 7 & 3 & 1 \\
8. Güçlü ipuçları & 3 & 4 & - & - \\
9. Hafif ipuçları & - & - & - & - \\
Toplam & 75 & 100 & 262 & 100 \\
\hline
\end{tabular}

Tablo 3.'te BDTK'ların ve İDTK'ların en çok başvurulan strateji açısından benzer stratejilere ve ulamlara yöneldikleri görülmektedir. Doğrudan eylem ifadesi stratejisi her iki grup tarafından da bu bağlamda en çok kullanılan strateji olmuştur. Ayrıca doğrudan eylem ifadesi stratejisinden sonra her iki grupta en çok istek ifadesi stratejisini kullanmıştır. Güçlü ipuçları stratejisi İDTK'larca tercih edilmezken BDTK'ların \%4'ü bu stratejiyi kullanmıştır. Beşinci bağlama ilişkin anadili konuşurlarından birinin doğrudan eylem ifadesi stratejisindeki yanıtı “Affedersiniz hanımefendi rica etsem bir fotoğrafımızı çekebilir misiniz?” (Katılımc1, 72) biçimindeyken aynı bağlamda ve aynı stratejide yabancı dil öğrenicilerinden birinin yanıtı "Pardon fotoğraf çeker misin lütfen?" (Katılımc1, 42) biçimindedir.

\subsection{Bilgi alma ulamında rica etme stratejilerinin dağılımı}

Çalışmada verilen bağlam içi durumlara göre bilgi alma ulamında kullanılan rica stratejileri şöyledir:

\section{Bağlam:}

Tatil için yaşadığınız şehirden farklı bir yere gittiniz. Fakat kalacă̆ınız şehirdeki otelin yerini bulamadınız. O esnada yoldan geçen birine kalacă̆ınız otelin adresini nasıl sorarsı$n ı z$ ? 
Tablo 4. Üçüncü Bağlama Yönelik Başvurulan Rica Etme Stratejilerinin Dağılımı

\begin{tabular}{lllll}
\hline Stratejiler & BDTK & \multicolumn{3}{c}{ İDK } \\
& $f$ & $\%$ & $f$ & $\%$ \\
\hline 1. Türetilebilir durum & 5 & 7 & 44 & 17 \\
2. Doğrudan eylem & 13 & 17 & 84 & 32 \\
3. Sınırlandırılmış eylem & 3 & 4 & 12 & 5 \\
4. Yer belirleme-Zorunluluk & 15 & 20 & 6 & 2 \\
5. İstek ifadesi & 31 & 41 & 112 & 43 \\
6. Öneri ifadesi & - & - & - & - \\
7. Hazırlayıcı durumlara atıf & 2 & 3 & 4 & 1 \\
8. Güçlü ipuçları & 5 & 7 & - & - \\
9. Hafif ipuçları & 1 & 1 & - & - \\
Toplam & 75 & 100 & 262 & 100 \\
\hline
\end{tabular}

Tablo 4.'te BDTK'ların ve IDTK'ların benzer stratejilere başvurduğu ve istek ifadesi stratejisinin bu bağlamda her iki grup tarafından da en çok kullanılan strateji olduğu görülmektedir. IDTK'lar tarafindan doğrudan eylem ve türetilebilir durum stratejisi de yüksek oranda kullanılmış, BDTK'ların \%41'i istek ifadesi stratejisini kullanırken sadece \%11'lik kısım dolaylı ricayı tercih ettiği için hazırlayıcı durumlar, güçlü ve hafif ipuçları stratejilerini kullanmıştır. IDTK'ların ise dolaylı düzey rica gerçekleştirim ulamı sınıfında yer alan bir strateji kullanmadığı görülmüştür. Üçüncü bağlama ilişkin BDTK'lardan birinin istek ifadesi stratejisindeki yanıtı "İyi günler ablacı̆̆ım buraya yeni geldim ve kalacağım otelin yerini bulamıyorum, siz bu otelin yerini biliyorsanı gösterebilir misiniz?" (Katılımc1, 36) biçimindeyken IDTK'lardan birinin yanıtı "Hey otelin yerine götürmenizi istesem olur mu?" (Katılımc1, 21) biçimindedir.

\section{Bağlam:}

Yakın bir zamanda tatile çıkacaksınız. Nereye gideceğinize henüz karar veremediniz. Bodrum'da yaşayan arkadaşınızdan Bodrum ile ilgili bilgileri nasıl istersiniz?

Tablo 5. Altıncı Bağlama Yönelik Başvurulan Rica Etme Stratejilerinin Dağılımı

\begin{tabular}{lllll}
\hline Stratejiler & BDTK & \multicolumn{3}{l}{ İTK } \\
& $f$ & $\%$ & $f$ & $\%$ \\
\hline 1. Türetilebilir durum & - & - & 22 & 9 \\
2. Doğrudan eylem & 3 & 4 & 25 & 10 \\
3. Sinırlandırılmış eylem & 8 & 11 & 45 & 17 \\
4. Yer belirleme-Zorunluluk & 11 & 15 & 6 & 2 \\
5. İstek ifadesi & 20 & 27 & 113 & 43 \\
6. Öneri ifadesi & 25 & 33 & 46 & 17 \\
7. Hazırlayıcı durumlara atıf & 3 & 4 & 5 & 2
\end{tabular}




\begin{tabular}{lllll} 
8. Güçlü ipuçları & 3 & 4 & - & - \\
9. Hafif ipuçları & 2 & 2 & - & - \\
Toplam & 75 & 100 & 262 & 100 \\
\hline
\end{tabular}

Tablo 5.'te grupların altıncı bağlama ilişkin kullandıkları stratejilerin dağılımları belirtilmektedir. Buna göre BDTK'lar \%33 oranla en çok öneri ifadesi stratejisini kullanırken IDTK'ların \%43 oranla istek ifadesi stratejisini kullandığ görülmektedir. Bunun yanında BDTK'ların türetilebilir durum stratejisi dışında tüm stratejilere yöneldiği görülürken, İDK'ların güçlü ve hafif ipuçları dışındaki tüm stratejileri kullandıkları görülmüştür. Altıncı bağlama ilişkin BDTK'ların öneri ifadesi stratejisindeki yanıtı "Dostum merhaba, tatile nereye gitsem karar veremedim, sence Bodrum nasıl?" (Katılımc1, 12) biçimindeyken aynı bağlamda ve aynı stratejide yabancı dil öğrenicilerinden birinin yanıtı "Kararsızım tatile Bodrum'a gelsem nasıl?" (Katılımc1, 134) biçimindedir.

\section{Bağlam:}

İş gezisi nedeniyle Türkiye'ye geldiniz ve telefonunuzu havaalanında yere düşürdüğünüzde telefonunuz çalışmadı. Acil olarak bir tamirci bulmak istiyorsunuz. O sırada havaalanında güvenlik görevlisini fark ettiniz. Güvenlik görevlisinden bu durumla ilgili nasıl yardım istersiniz?

Tablo 6. Sekizinci Bağlama Yönelik Başvurulan Rica Etme Stratejilerinin Dağılımı

\begin{tabular}{lllll}
\hline Stratejiler & BDTK & & İDK & \\
& $f$ & $\%$ & $f$ & $\%$ \\
\hline 1. Türetilebilir durum & - & - & 22 & 8 \\
2. Doğrudan eylem & 18 & 24 & 139 & 53 \\
3. Sınırlandırılmış eylem & 9 & 12 & 18 & 7 \\
4. Yer belirleme-Zorunluluk & 25 & 33 & 41 & 16 \\
5. İstek ifadesi & 15 & 20 & 32 & 12 \\
6. Öneri ifadesi & - & - & - & - \\
7. Hazırlayıcı durumlara atıf & 2 & 3 & 10 & 4 \\
8. Güçlü ipuçları & 4 & 5 & - & - \\
9. Hafif ipuçları & 2 & 3 & - & - \\
Toplam & 75 & 100 & 262 & 100 \\
\hline
\end{tabular}

Tablo 6.'da BDTK'lar tarafindan en çok yer belirleme-zorunluluk stratejisi kullanılırken, IDTK'lar tarafından \%53 oranla doğrudan eylem ifadesi stratejisinin kullanıldı̆̆ 1 görülmektedir. BDTK'lar doğrudan, dolaylı ve geleneksel olmayan dolaylı düzey olan üç rica gerçekleștirim ulamından da stratejiler kullanmayı tercih etmişlerdir. Sekizinci bağlama ilişkin BDTK' lardan birinin yer belirleme-zorunluluk ifadesi stratejisindeki yanıtı "Pardon telefonumu yere düşürdügüum için kapandı acil annemi aramalıyım, burada tamirci var mı 
bana bilgi verebilir misiniz?” (Katılımcı, 3) biçimindeyken aynı bağlamda ve aynı stratejide IDTK'lardan birinin yanıtı "Bayım telefonu tamir ettirmek zorundayım." (Kat1lımc1, 132) biçimindedir.

\section{Bă̆lam:}

Taksiye bineceksiniz ve yanınızda nakit para yok. En yakın bankamatikten para çekmeniz gerekiyor. O sırada yoldan geçen arkadaşınıza bankamatiğin yerini nasıl sorarsınız?

Tablo 7. Onuncu Bağlama Yönelik Başvurulan Rica Etme Stratejilerinin Dağılımı

\begin{tabular}{lllll}
\hline Stratejiler & BDTK & & İDK & \\
& $f$ & $\%$ & $f$ & $\%$ \\
\hline 1. Türetilebilir durum & 3 & 4 & 40 & 15 \\
2. Doğrudan eylem & 5 & 7 & 64 & 24 \\
3. Sınırlandırılmış eylem & 4 & 5 & 21 & 8 \\
4. Yer belirleme-Zorunluluk & 13 & 17 & 35 & 14 \\
5. İstek ifadesi & 28 & 37 & 97 & 37 \\
6. Öneri ifadesi & - & - & - & - \\
7. Hazırlayıcı durumlara atıf & 2 & 3 & 5 & 2 \\
8. Güçlü ipuçları & 9 & 12 & - & - \\
9. Hafif ipuçları & 11 & 15 & - & - \\
Toplam & 75 & 100 & 262 & 100 \\
\hline
\end{tabular}

Tablo 7.' de grupların onuncu bağlama ilişkin verilen yanıtlarının dağılımları görülmektedir. Bu doğrultuda BDTK'lar ve İDTK'lar tarafından onuncu bağlamda en çok istek ifadesi rica stratejisi kullanılmıştır. BDTK'ların rica etmede öneri ifadesi dışındaki tüm stratejileri kullandığı görülmektedir. İDTK'ların \%98'inin doğrudan anlatım ve geleneksel dolaylı düzey rica gerçekleştirim ulamlarındaki stratejileri kullandıkları ve diğer stratejilere değinmedikleri tabloda belirtilmektedir. Onuncu bağlama ilişkin BDTK'lardan birinin istek ifadesi stratejisindeki yanıtı "Aliciğim seni iyi ki gördüm yanımda nakit hiç param kalmadı burada en yakın bankamatik nerede tarif eder misin?" (Katılımc1, 18) biçimindeyken aynı bağlamda ve aynı stratejide IDTK'lardan birinin yanıtı "Affedersiniz yakında bankamatik istiyorum” (Katılımc1, 12) biçimindedir.

\section{3. İzin/Onay isteme ulamında rica etme stratejilerinin dağılımı}

Çalışmada verilen bağlam içi durumlara göre izin/onay isteme ulamında kullanılan rica stratejileri şöyledir:

\section{Băglam:}

Otobüste yolculuk yapıyorsunuz. Yanınızdaki kişi gazete okuyor. Okuduktan sonra gazetesini koyduğunu gördünüz. Okumak için gazeteyi alıp alamayacağınızı nasıl sorarsınız? 
Tablo 8. Birinci Bağlama Yönelik Başvurulan Rica Etme Stratejilerinin Dağılımı

\begin{tabular}{lllll}
\hline Stratejiler & BDTK & \multicolumn{3}{c}{ İDK } \\
& $f$ & $\%$ & $f$ & $\%$ \\
\hline 1. Türetilebilir durum & 5 & 7 & 31 & 12 \\
2. Doğrudan eylem & 3 & 4 & 52 & 20 \\
3. Sınırlandırılmış eylem & 8 & 11 & 121 & 46 \\
4. Yer belirleme-Zorunluluk & - & - & - & - \\
5. İstek ifadesi & 32 & 42 & 42 & 16 \\
6. Öneri ifadesi & - & - & - & - \\
7. Hazırlayıcı durumlara atıf & 15 & 20 & 7 & 3 \\
8. Güçlü ipuçları & 8 & 11 & 6 & 2 \\
9. Hafif ipuçları & 4 & 5 & 3 & 1 \\
Toplam & 75 & 100 & 262 & 100 \\
\hline
\end{tabular}

Tablo 8.'de grupların birinci bağlama yönelik dağılımları belirtilmektedir. Buna göre BDTK'lar \%42 oranla en çok istek ifadesi stratejisini kullanırken IDTK'lar \%46 oranla sınırlandırılmış eylem ifadesi stratejisine yönelmiştir. Birinci bağlama ilişkin BDTK'lardan birinin istek ifadesi stratejisindeki yanıtı "Pardon amcacı̆̆ım ĕger gazetenizi okumanız bittiyse mümkünse ben de okuyabilir miyim?" (Katılımc1, 51) biçimindeyken aynı bağlamda ve aynı stratejide IDTK'lardan birinin yanıtı "Affedersin gazetenin olur mu alsam?” (Katılımc1, 40) biçimindedir.

\section{Bağlam:}

Okuldan sonra arkadaşlarınla birlikte sinemaya gideceksiniz. Eve geç geleceğini söylemek için anneni arayacaksın ama telefonun yanında değil. Alt sınıftaki bir öğrencinin elinde telefon olduğunu gördün. Yanına giderek bu kişiden telefonunu kullanmayı nasıl istersin?

Tablo 9. İkinci Bağlama Yönelik Başvurulan Rica Etme Stratejilerinin Dă̆ılımı

\begin{tabular}{lllll}
\hline Stratejiler & BDTK & & İDTK & \\
& $f$ & $\%$ & $f$ & $\%$ \\
\hline 1. Türetilebilir durum & 3 & 4 & 46 & 18 \\
2. Doğrudan eylem & 8 & 11 & 69 & 26 \\
3. Sınırlandırılmış eylem & 12 & 16 & 25 & 10 \\
4. Yer belirleme-Zorunluluk & 19 & 25 & 19 & 7 \\
5. İstek ifadesi & 16 & 21 & 103 & 39 \\
6. Öneri ifadesi & - & - & - & - \\
7. Hazırlayıcı durumlara atıf & 8 & 11 & - & - \\
8. Güçlü ipuçları & 6 & 8 & - & - \\
9. Hafif ipuçları & 3 & 4 & - & - \\
Toplam & 75 & 100 & 262 & 100 \\
\hline
\end{tabular}


Tablo 9.'da grupların ikinci bağlama yönelik dağılımları görülmektedir. Bu doğrultuda BDTK'lar \%25 oranla en çok yer belirleme-zorunluluk stratejisini kullanırken IDTK'ların \%39 oranla istek ifadesi stratejisini kullandığı görülmektedir. İkinci bağlama ilişkin BDTK'lardan birinin istek isteme stratejisindeki yanıtı "Kardeşim kusura bakma telefonumu evde unutmuşum senin telefonundan bir dakika annemi arayabilir miyim?" (Katılımc1 9) biçimindeyken aynı bağlamda ve aynı stratejide IDTK'lardan birinin yanıtı "Telefonunu alabilir miyim?" (Katılımc1, 81) biçimindedir.

\section{Bağlam:}

Büyük bir bilgisayar firmasında sekreter olarak çalışıyorsunuz. Normalde saat 5 'te işten çıkıyorsunuz ama bugün bankada işiniz olduğu için iki saat erken çıkmanız gerekiyor. Bu durumda müdürünüzden nasıl izin istersiniz?

Tablo 10. Yedinci Bă̆lama Yönelik Başvurulan Rica Etme Stratejilerinin Dağılımı

\begin{tabular}{lllll}
\hline Stratejiler & BDTK & & İTK & \\
& $f$ & $\%$ & $f$ & $\%$ \\
\hline 1. Türetilebilir durum & 2 & 3 & 12 & 5 \\
2. Doğrudan eylem & 5 & 7 & 75 & 29 \\
3. Sinırlandırılmış eylem & 8 & 11 & 52 & 20 \\
4. Yer belirleme-Zorunluluk & 27 & 36 & 91 & 35 \\
5. İstek ifadesi & 25 & 33 & 23 & 8 \\
6. Öneri ifadesi & - & - & - & - \\
7. Hazırlayıcı durumlara atıf & 5 & 6 & 9 & 3 \\
8. Güçlü ipuçları & 3 & 4 & - & - \\
9. Hafif ipuçları & - & - & - & - \\
Toplam & 75 & 100 & 262 & 100 \\
\hline
\end{tabular}

Tablo 10.'da grupların yedinci bağlama yönelik dağılımları gösterilmektedir. Bu dağılımlara göre BDTK'lar \%36 oranla İDTK'lar ise \%35 oranla en çok yer belirleme-zorunluluk stratejisini kullanmışlardır. İDTK'lar \%29 oranla doğrudan eylem ifadesi stratejisine başvururken rica gerçekleştirimini daha çok doğrudan anlatım ile gerçekleştirmişlerdir. BDTK'lar $\% 4$ oranla geleneksel olmayan dolaylı düzey rica gerçekleştirim ulamında yer alan rica stratejilerini kullanırken İDTK' ların hiçbirinin bu gerçekleştirim ulamında bulunan rica stratejilerini kullanmadığ 1 görülmüştür. Yedinci bağlama ilişkin BDTK'lardan birinin yer belirlemezorunluluk ifadesi stratejisindeki yanıtı "Affedersiniz müdürüm bankaya gitmek zorundayım bugün işten iki saat erken çıkmam mümkün mü?” (Katılımc1, 13) biçimindeyken aynı bağlamda ve aynı stratejide yabancı dil öğrenicilerinden birinin yanıtı "Patronum bugün iki saat önce çıkmak zorundayım." (Katılımc1, 265) biçimindedir. 


\section{Bă̆lam:}

Sabah geç uyandınız ve kursa yetişmeniz gerekiyor. Acele evden çıktı̆̆ınız için otobüs durağına geldiğinizde cüzdanınızı evde unuttuğunuzu fark ettiniz. Durakta olan birinden, otobüse binmek için onun kartını kullanmayı ona nasıl söylersiniz?

Tablo 11. Dokuzuncu Bağlama Yönelik Başvurulan Rica Etme Stratejilerinin Dağılımı

\begin{tabular}{lllll}
\hline Stratejiler & BDTK & & İDK & \\
& $f$ & $\%$ & $f$ & $\%$ \\
\hline 1. Türetilebilir durum & - & - & 19 & 7 \\
1. Doğrudan eylem & 4 & 5 & 109 & 42 \\
2. Sinırlandırılmış eylem & 3 & 4 & 41 & 16 \\
3. Yer belirleme-Zorunluluk & 5 & 7 & 28 & 11 \\
4. İstek ifadesi & 13 & 18 & 53 & 20 \\
5. Öneri ifadesi & 25 & 33 & 12 & 4 \\
6. Hazırlayıcı durumlara atıf & 7 & 9 & - & - \\
7. Güçlü ipuçları & 12 & 16 & - & - \\
8. Hafif ipuçları & 6 & 8 & - & - \\
Toplam & 75 & 100 & 262 & 100 \\
\hline
\end{tabular}

Tablo 11.'de grupların dokuzuncu bağlama yönelik dağılımları belirtilmektedir. Buna göre BDTK'ların \%33 oranla en çok öneri ifadesi rica stratejisini kullandığı görülürken IDTK'ların \%42'sinin doğrudan eylem ifadesi stratejisine yöneldiği görülmüştür. Bunun yanında BDTK'ların geneli geleneksel ve geleneksel olamayan dolaylı düzey rica gerçekleştirimlerini içeren stratejiler kullanmıştır. İTK'larda ise \%96'lık kısım doğrudan anlatım içeren rica stratejilerini kullanmıştır. Dokuzuncu bağlama ilişkin BDTK'lardan birinin öneri ifadesi stratejisindeki yanıtı "Affedersin ablacı̆̆ım kartımı evde unutmuşum sana parasını versem kartını kullanabilir miyim?" (Katılımcı, 20) biçimindedir. Aynı bağlam ve aynı stratejide bir IDTK ise "Kartım evde sen kart ver." (Katılımc1, 52) biçiminde yanıt vermiştir.

\section{Sonuç ve tartışma}

Araştırmanın ve değerlendirmelerin temelini oluşturan Blum-Kulka ve Olshtain (1984)' in sınıflandırmasında bulunan dokuz rica stratejisinden ikinci, üçüncü, altıncı ve onuncu bağlamlarda İDTK'lar tarafından en çok istek ifadesi stratejisi kullanılmıştır. Rica etme ediminde katılımcılar bazı durumlarda aynı yanıtta birden çok stratejiye yönelmişlerdir. Bu da Austin (1970)' in çalışmasında belirttiği doğru ve yanlış stratejinin olmadığı, uygun ve uygun olmayan stratejinin olduğu düşüncesiyle örtüşmektedir. Genel olarak yönelticiler, özelde ise rica söz edimlerinin doğru ya da yanlış biçiminde değil, söz edimleri kuramı açısından uygun ya da uygun olmayan biçiminde değerlendirilmesi önemli bir sınırlılıktır. Bunun yanında IDTK'lar bazı durumlarda baskın olan bir stratejiye ek olarak ikinci bir strateji daha kullanmışlardır. İngilizceye ilişkin yapılan bir araştırmada da farklı milletlerden olan yabancı 
öğrencilerin bağlamlara göre uygun stratejileri seçemedikleri görülmüştür (Moon 2001'den aktaran Bayat, 2017: 3). Moon'un bahsettiği sonuç, bu araştırmada bulunan bazı bağlamlarda IDTK'ların BDTK'lardan farklı rica stratejilerini tercih etmeleri ve uygun stratejiyi seçememeleri sonucuyla tutarlidir.

$\mathrm{Bu}$ çalışmadan elde edilen sonuçlara göre, BDTK'ların rica etme ediminin bilgi alma ve izin/onay isteme ulamlarında IDTK'lardan farklı stratejileri kullandıkları, fakat eylem isteme alt ulamında genellikle aynı stratejilere değindikleri görülmüştür. Bağlamlar karşısında verilen yanıtları BDTK'larda kişiler arası ilişkinin, yaşın ve toplumsal statünün daha çok belirlediği, yabancı öğrencilerde ise bu ilişkinin ya da statünün tam olarak bilinmemesi nedeniyle verilen yanıtları çok yönlendirmediği görülmüştür. Bunların yanında rica söz edimlerinin gerçekleştiriminde BDTK'lar tarafından dolaylılık ve sezdirimlere daha çok yer verilirken, yabancı öğrencilerde bu durumun daha çok doğrudan bildirim kullanımı biçiminde ortaya çıkmaktadır. BDTK'ların örtük anlamları anlamalarında, dilbilgisel kullanımlarında, iletişim yetisinde vb. yönlerde daha başarılı olmalarıbu durumun nedeni olarak düşünülmektedir. Ayrıca IDTK'ların rica strateji çeşitlerini gerektiğince kullanamadıkları ve kendi dillerinde bulunan dolaylı kullanımları hedef dile aktaramadıkları sonucu, Jalilifar (2009: 46-61)'ın bulgularıyla örtüşmektedir. Brown ve Levinson (1987: 45-48)'ın çalışmasında elde ettiği yüksek dolaylılık gerçekleştirim çeşitleri yüksek nezaket düzeylerine neden olabilir sonucu ile bu çalışmada ulaşılan, dolaylılık kullanımlarının olduğu stratejilerde öğrencilerin genellikle "affedersiniz, pardon, hanımefendi, beyefendi" gibi nezaket sözcüklerini de kullanması sonucunun benzer olduğu görülmektedir. Harlow (1990: 328-349)'un da çalışmasında belirttiği gibi dilsel düzeyi yüksek olmayan IDTK'ların dilbilgisel eksiklikleri ya da nezaket kurallarına ilişkin bilgilerinin durumu da rica gerçekleştirim biçimleri belirleyicidir. Gökmen ve Dilber (2011: 44-60)' in çalışmasında dil edinimi için kullanılan alıştırmalarda öğrencilerin günlük hayatta daha çok karşılaşabilecekleri örnekler tercih edilerek öğrencilerin söz edim bilgilerinin gelişimi kolaylıkla oluşturulabilir sonucu ile bu çalışmanın bulguları benzerlik göstermektedir. Ayrıca bu çalışmada değinilen söz edim kuramı ışığında ele alınan rica söz ediminin İDTK'lar tarafından edinilmesinde yaşın, toplumun, kültürün belirleyicii olması, Aslan (2005: 114-117)'ın değerlendirmeleri ile örtüşmektedir. Son olarak, bu çalışmanın bulguları Polat (2010: 454)'ın IDTK'ların dilsel art alanları ne kadar iyi olursa olsun, günlük yaşantıda beklenen iletişimsel edinci yeterince gösteremedikleri yönündek bulguyla da örtüşmektedir.

Edimbilimsel edinç, bağlama yönelik hedeflenen amacı gerçekleştirmek için dili kullananların dili işlevsel olarak kullanabilmesi biçiminde açıklanır (Bayat, 2012: 215-217). Aynı zamanda toplumdilbilimsel edincin edimsel edincin bir parçası olduğu bilinerek, dili kullanan kişinin söz edimini gerektiği biçimde kullanması ve anlaması için ortaya çıkan toplumsal bağlamın etkisini ve kültürü dikkate alması gerekir. Bu çalışmada yabancı katılımcıların farklı stratejilere yönelmiş olmalarında kültürel bilgi eksikliğinden kaynaklanan bağlamı tam olarak anlayamama durumunun da belirleyici olduğu görülmektedir. Eylem isteme alt ulamında rica ediminde BDTK'lar doğrudan, dolaylı ve geleneksel olmayan dolaylı biçimindeki dilsel oluşumları kullanırken İDTK'ların doğrudanlığı içeren fakat daha kaba karşılanan stratejileri kullandığı sonucu ortaya çıkmıştır. Bu sonuç, gerek Lund ve Duchan (1988: 31-37)'ın değindiği biçimiyle gerekse Eken (2008: 22-25)'in çalışmalarıyla örtüşmektedir 
Araştırmada bilgi alma alt ulamındaki rica edimlerinde bulunan dört bağlamın ikisinde grupların daha çok yöneldiği strateji benzerken diğer ikisinde kullanılan stratejiler farklılık göstermektedir. Araştırmada kullanılan bağlamlarda kişiler arası ilişkinin, yaşın, toplumsal statünün, psikolojik mesafenin ve dayatma derecesinin BDTK'ların yanıtlarını daha çok belirlediği için iki grup arasında kullanılan stratejilerde farklılık oluştuğu düşünülmektedir.

Araştırmada izin/onay isteme alt ulamında rica edimlerinde bulunan dört bağlamın üçünde gruplar tarafından daha çok kullanılan strateji farklı iken birinde kullanılan stratejiler aynıdır. Bağlamda oluşturulan farklı ipuçları konuşucunun hangi stratejiyi tercih edeceği konusunda yardımcı olmaktadır. İDTK'larda dil edinim düzeyinin gelişmesiyle birlikte izin ve onay isteklerinin netleştiği, buna yönelik kullanılan stratejilerin çeşitlendiği görülmektedir.

Rica söz edimi bu çalışmanın odağını oluşturmaktadır. Buradan yola çıkarak, araştırmacıların farklı söz edimlerinin öğretimine ilişkin yapacakları çalışmalar ulusal ve uluslararası alanyazına katkı sağlayacaktır. Bu çalışma rica söz edimlerinin kullanımlarının doğrudan davranış düzeyini incelerken öğrenenlerin dil edinim sürecini incelememiştir. Gelecekte yürütülecek çalışmalarda dil edinim sürecinde söz edimlerinin öğretimi, incelik stratejilerinin kullanımı gibi konularla süreçte ortaya çıkan sorunlar araştırılabilir.

\section{Kaynaklar}

Aktaş, T. (2005). Yabancı dil öğretiminde iletişimsel yeti. Selçuk Üniversitesi Sosyal Bilimler Enstitüsü Dergisi, 12, 45-57.

Aslan, S. (2005). Türkiye Türkçesinde sezdirmeye dayalı rica stratejileri. Modern Türklük Araştırmalarl Dergisi, 1, 114-117.

Austin, J. L. (1970). Quand dire, c'est faire (çev. G. Lane.). Paris: Editions du Seuil.

Austin, J. L. (2009). Söylemek ve yapmak. (çev. L. Aysever). Istanbul: Metis.

Balc1, A. (2009). Sosyal bilimlerde araştırma, yöntem, teknik ve ilkeler. Ankara: PegemA

Bayat, N. (2012). A study on the use of speech acts. Procedia-Social and Behavioral Sciences, 70, 213-221.

Bayat, N. (2017). Türkçenin yabancı dil olarak öğretiminde şikâyet ve özür edimine ilişkin görünümler. Pamukkale Üniversitesi Eğitim Fakültesi Dergisi, 41, 1-16.

Brown, P., \& Levinson, S. C. (1987). Studies in interactional sociolinguistics, 4. Politeness: Some universals in language usage. New York, NY, US: Cambridge University.

Blum-Kulka, S. \& Olshtain, E. (1984). Requests and apologies: A cross-cultural study of speech act realization patterns (CCSARP). Applied Linguistics, 5(3), 196-213.

Çelebi, V. (2014). Günlük dil felsefesi ve Austin'in söz edimleri kuramı. Beytulhikme: An International Journal of Philosophy, 4(1), 73-89.

Demircan, Ö. (2005). Yabancl-dil öğretim yöntemleri. İstanbul: Der.

Dore, J. (1978). Conditions ort he acquisition of speech act. In: I. Markova (Ed.), The Social Context of Language (pp. 87-111). Chichester: Wiley.

Eken, N. T. (2008). 4;00-6;00 Yaş aralı̆̆ında iletişimsel amaç kullanımı. Yayınlanmamış yüksek lisans tezi. Ankara Üniversitesi Sosyal Bilimler Enstitüsü, Ankara. 
Ellis, R. (1994). The study of second language acquisition. Newyork: Oxford University.

Erdem, B. (2014). Yabanc1 dil olarak Türkçe öğretiminde iletişim yeteneklerinin geliştirilmesine etkileşimsel toplumbilimsel bir yaklaşım. D. Yaylı ve Y. Bayyurt, (Ed.), Yabancılara Türkçe öğretimi:Politika yöntem ve beceriler içinde, (3. bask1, s. 115-142). Ankara: Anı.

Gass, S. M. \& Houck, N. (1999). Interlanguage refusals: a cross-cultural study of Japanese-English. Berlin: Mouton de Gruyter.

Gökmen, S. ve Dilber, N. Ç. (2011). Türkçe derslerinde söz edimlerin öğretimi üzerine bir değerlendirme. Dil Dergisi, 154, s. 44-60.

Harlow, L. L. (1990). Do they mean what they say? Sociopragmatic competence and second language learners. The Modern Language Journal, 74, 328-349.

Jalilifar, A. (2009). Request strategies: cross-sectional study of Iranian eff learners and Australian native speakers. English Language Teaching Journal, 2, 46-61.

Kıran, Z. ve Kıran, A. (2013). Dilbilime giriş. Ankara: Seçkin.

Kocaman, A. (2008). Yabancı dil öğretiminde yeni yönelimler. Türk Dili Dergisi [Dil Öğretim Özel Sayıs $], 3-4,379-380$.

Lund, J. N. ve Duchan, J. F. (1988). Assessing children's language in naturalistic contexts (2th ed.). New Jersey: Prentice-Hall.

Özdemir, A. (2016). Yabancı dil olarak Türkçe ögrenen öğrencilerin söz edimlerini anlama düzeyleri. Yayımlanmamış yüksek lisans tezi, Hacettepe Üniversitesi Türkiyat Araştırmaları Enstitüsü, Ankara.

Polat, Y. (2010). Yabancı dil ögretiminde söz edimleri. Yayınlanmamış doktora tezi. Ankara Üniversitesi Sosyal Bilimler Enstitüsü, Ankara.

Searle, J. R. (2000). Söz edimleri. (çev. L. Aysever). Ankara: Ayraç. (Orijinal çalışmanın basım tarihi 1991).

Searle, J. R. (2006). Zihin, dil, toplum. (çev. A. Tural).İstanbul: Litera. (Orijinal çalışmanın basım tarihi 1998).

Tabar, M. S. (2012). Cross-cultural speech act realization: the case of requests in the persian and Turkish speech of Iranian speakers. International Journal of Business and Social Science, 13, 237-243.

Trosborg, A. (1995). Requests, complaints and apologies. Berlin: Mouton de Gruyter.

Yıldırım, A. ve Şimşek, H. (2006). Sosyal bilimlerde nitel araştırma yöntemleri. Ankara: Seçkin. 